\title{
The Return of China, Post-Cold War Russia, and the Arctic: Changes on Land and at Sea
}

\section{Abstract:}

With a long view of the Arctic in international politics and economics, the paper discusses the effects of political and economic power transitions for the Arctic, focusing on Sino-Russian relations. The Arctic has in the last decade received new attention from new quarters of the world, especially Asian emerging powers, which reflects climate change and power transition/globalization. The focus here is on cases of cross-border exchanges in agriculture, raw materials, processed goods, energy and Arctic shipping. The chapter discusses how Sino-Russian relations in this region reflect general trends of Russia and China in a post-Cold War globalized international political and economic system. Russia for both domestic and international reasons struggles to find its post-Cold War position in the international political and economic system, which affects its place between the West and China. Russia's entire northern boundary is the Arctic, with the longest Arctic coastline of all five Arctic coastal states. To in any way relegate any parts of its Arctic marine area currently defined by the Law of Sea as its EEZ to any international or Chinese authority would diminish Russia's power. China has since the late 1970s experienced phenomenal economic growth, which is the strongest single driver of political and economic power transition in the international system. This power transition also defines China's relation to the Arctic and to Russia. China now terms itself a "near Arctic" nation, has previously described the Arctic as a common heritage of mankind, and seeks to further its influence in the Arctic.

Keywords: China, Russian Far East and Eastern Siberia, Pacific Arctic, cold war, power transition, Bering Region

\section{Highlights}

1) The Arctic is historically embedded in the international system

2) End of Cold War and Rise of China greatly Arctic today

3) Pacific Arctic is little known to Nordic and North Atlantic observers

4) Sino-Russian relations in Pacific Arctic reflect global geopolitics

5) Russia is distrustful of Chinese natural resource investment

\section{Introduction}

The Arctic has received new outside attention for about a decade. Much of this attention - especially popular, but also academic - has focused on local factors in the Arctic. The focus has often been on energy, minerals and shipping lanes made accessible by climate change (Borgerson 2008). There has been a lack of attention to the wider forces of globalization driving this attention to the Arctic. Therefore, the popular and academic discussion of the Arctic benefits from showing the place of the Arctic in the international system before, now and in the future. For the last 25+ years, those systemic changes are the end of the Cold War followed by globalization. The chapter discusses the effects of these international political and economic systemic shifts for 
the Arctic with focus on China and Russia based on a foundation of how the international systemic changes affect Russia and China: the end of the Cold War and globalization/power transition.

Before turning to the recent international changes of the end of the Cold War and globalization, it is valuable to remember that the North American, North Atlantic and Eurasian Arctic has been economic, military and scientific theatres for European and Western powers since medieval times. For instance, North Atlantic fish fed medieval Europe during Lent. The Royal Navy and the German Kriegsmarine fought each other for primacy of the North Atlantic and Barents Seas in two world wars. During the Cold War, US and Soviet submarine-based strategic nuclear weapons systems and anti-subware warfighting systems were heavily deployed there (Heininen, Southcott 2010).

\section{China, Globalization and the Arctic}

China's and Asia's new interest in the Arctic is driven by forces outside the Arctic and not local factors: environmental and political-economic globalization. Environmental globalization is primarily climate change here, which is particularly pronounced in the Arctic (and Antarctic). The rising Asian economic and political powers are vulnerable to climate change, such as sea-level rise threatening major economic and population centers along the coast of China. They have scientific ambitions matching their economic and political rise, and therefore also climate scientific ambitions, where Polar areas are central areas of research (Li, Bertelsen 2013).

The other driving factor in the interest of rising Asian powers in the Arctic is political and economic globalization and the international politics concept of "power transition", which describes the changing relative power of rising and declining great powers. Such power transition is one of the most influential aspects of international history, very hard to manage peacefully, and has often resulted in devastating wars as the Napoleonic Wars or the two world wars. Popular and academic audiences must remember that power transition has affected the Arctic historically and political-economic globalization does so today to great extent (Heininen, Southcott 2010).

Especially China's phenomenal growth is tilting the international political and economic system also with effects on the Arctic and Sino-Russian relations. Since instituting its Open Door policy in the late 1970s, China has experienced historically unprecedented economic growth of around $10 \%$ per year, which has returned it to its historical place in the world economy. It is correct to emphasize the "return" of China in the world economy in light of China and Asia's historical relative place in the world economy. This economic growth has brought China from being a poor developing country based on agriculture and a 1/20th of the US economy to being at par with the US economy in terms of purchasing power parity. The other Asian Arctic Council observer states, India, Japan, Singapore and South Korea have also grown markedly in recent years and decades spearheaded by Japan in the after-war years (Li, Bertelsen 2013).

China has high ambitions in science, technology, research, development and innovation for international and domestic reasons. Ambitions in, for instance, space or Polar science show China as a great power. China is forced to transition its economy from an investment- and factor-input-driven growth model to an innovationand consumption-driven growth model. Both drives a great expansion of research and education in China (Lundvall et al. 2009, Schwaag Serger 2009, Xie, Zhang \& Lai 2014, Cao, Suttmeier \& Simon 2009, Schaaper 2009, Xu 2008, Huang, Gouveia \& Varum 2007). The interconnections between Arctic climate science and 
Chinese climate is presented as an argument for China as a legitimate participant in Arctic governance. This is supportive of the often heard argument that the "Arctic is a "global commons" which no small group of nations can govern. And is further supported by the argument that China is a "near Arctic" country. China argues based on (Arctic) climate science that it is affected by (Arctic) climate change to legitimize a role for in Arctic governance. Climate change is feared to affect Chinese agriculture and thereby food security and social stability. Teleconnections between Arctic climate and Chinese climate is presented as an argument for China as a legitimate participant in Arctic governance. The Chinese population and especially economy is overwhelmingly concentrated along the low coastline of China, so sea level rise threatens key economic and population centers in China (Li, Bertelsen 2013).

Political and economic globalization also explain China's interest in the Arctic. Here it is important to see the Arctic in a global context and not mistakenly believe that China has a particular interest in the Arctic compared to other regions of the world. There has in some Arctic popular and research circles been a tendency to see the Arctic as high priority for China. Such a view is naturally based on dissociating China's Arctic interest from the general development of China's place in the international system. A remark at the Aalborg University workshop on "The Arctic Nexus in Asian-Nordic+ Relations" 5-7 November 2013 by Dr SU Ping of Tongji University is illustrative: "when I am in Arctic conferences, lots of people talk about China, when I am in China, only a few people talk about the Arctic." This remark by Dr SU was surprising to some of the Arctic participants in the workshop. They had difficulty seeing what would be an enormous engagement in a small Arctic community as negligible in a Chinese context. To understand China's interest in the Arctic among its myriad other domestic and international interests, it is useful to look at what the Chinese Communist Party defines as its core interests and the political guiding principle of President XI Jinping of the "Chinese Dream".

A core interest of the Chinese Communist Party is political stability and the continued rule by the Party. To achieve this goal, continuous economic growth must be ensured. The investment- and production factor-driven growth of China so far has required enormous inputs of energy and raw materials. This input has made China the predominant importer of energy and raw materials, which has dictated international energy and commodities markets driving up prices and feeding the economic boom of many commodities producing countries around the world. China has and continues to source energy and raw materials from around the world - which is clear from, for instance, its controversial energy, mining and other commodities producing investments in Africa, Latin America and further. This global sourcing of energy and raw materials for fueling continuous Chinese economic growth is the necessary framework to understand China's interest in Arctic energy and raw materials. The Arctic is one possible source among many others, it is particularly environmentally and technically challenging, but it is composed by strong, stable states providing political stability unlike many other source regions. Despite the export driven nature of the Chinese economy the key to its success is the import driven nature of fuel for its industry. Without Arctic-sourced imported fuel, its other sources support extremely long supply lines, which is perilous. Direct access to industrial fuel from the Arctic, the Russian or its own (which at present it does not have) provides assurance of a stable future. Of course, the same is true for the other Asian countries (Li, Bertelsen 2013, Bertelsen, Li \& Gregersen 2016).

Another aspect of the domestic political necessity of continued high economic growth is trade. Chinese economic growth has been export-driven with overwhelmingly sea-based trade. China is therefore putting much strategic emphasis in developing its global trade-avenues. This is most clear in the "One Belt, One Road" policy of developing both the tradition Malacca Strait and Suez Canal connection to the Indian Ocean and 
Europe and the overland connection through Central Asia to the Middle East and Europe. Possible new Arctic sea lanes along the Northern Sea Route north of Russia (historically known in the West as the Northeast Passage), the Northwest Passage north of Alaska and Canada, or a Transpolar route are therefore the marginal alternatives that a great power can afford to entertain as strategic hedging and experimenting. Overall it is clear that China has a deep strategic interest in security of supply of energy, raw materials and sea-lanes, which is the framework for its Arctic interest. President XI Jinping has declared the "Chinese Dream" to be the guiding vision of his policy. It is a dream of both domestic prosperity and international recognition of great power status. The Arctic as a source region of energy and raw materials therefore supports the dream of domestic prosperity, as explained above, and participation in Arctic governance - as in global and regional governance around the world - supports the external dream of international recognition (Li, Bertelsen 2013, Bertelsen, Li \& Gregersen 2016).

\section{Post-Cold War Russia in the Arctic}

The long aftermath of the Cold War in the international system has been overshadowed by the power transition driven by the rise of China. This long aftermath of the Cold War has forcefully surfaced in the shape of the Ukraine crisis, which plays a key role for the Arctic today and Sino-Russian relations in the region.

The historical international system context for the current Arctic situation under the Ukraine crisis deserves to be outlined to remind of the systemic embeddedness of the Arctic. Russia as the successor state of the USSR went through politically, economically and socially tumultuous times during President Boris Yeltsin's rule in the 1990s. Russia's international status was much diminished. It lost its sphere of influence in Eastern and Central Europe, which was integrated into the West with NATO- and EU-membership. Russia lost the overseas influence of the USSR in many developing countries. The domestic affairs of Russia were significantly stabilized since Vladimir Putin replaced Yeltsin as president in 1999. The above mentioned boom in energy and commodity prices driven by Chinese and emerging market growth stimulated the Russian public and private economy greatly. However, Russia has continued to be marked by struggle over its post-USSR place in the international system and over the nature of its domestic political and economic system.

Soviet/Russian political, economic and military dominance over Central and Eastern Europe unravelled with the fall of communist regimes in these countries in the autumn of 1989. In the years and decades following, Russia lost this previous sphere of influence as many of these countries joined the EU and NATO against the will of Russia, which Russia could not force upon these countries and the West. However, with the NATO Bucharest declaration of 2007 inviting Georgia and Ukraine to become NATO-members, the West had overextended itself into a Russian sphere of influence. The brief 2008 Russian-Georgian war put an effective end to Georgia's NATO ambitions.

The EU has strategically used its "Neighborhood Policy" to attempt to surround itself with liberal democracies and well-functioning market economies to the South and East. This strategy has generally been successful to the east. The EU and Ukraine negotiated a partnership to be signed in the autumn of 2013. However, then President of Ukraine Viktor Yanukovych withdrew from the planned partnership and turned politically and economically towards Russia. This decision led to widespread protests in Kiev, the Euro-Maidan protests, in late 2013 and early 2014. When the Ukrainian government used excessive and deadly force against the protesters, it lead to the ultimate ouster of President Yanukovych. Russia saw its economic, political and 
military interests in Ukraine in free fall with the fall of Yanukovych and responded with more or less covert interventions in the Crimea and Eastern Ukraine. Russia's annexation of Crimea is an unprecedented change of borders by force in post World War II European politics. The intervention in Eastern Ukraine has created one of the frozen conflicts (as in South Ossetia and Abkhazia in Georgia and Transnistria in Moldova) which Russia has used to try to secure a sphere of influence while forced to retreat from Eastern Europe and the Caucasus (Mearsheimer 2014).

Especially the annexation of Crimea was an unacceptable challenge to Western interests in terms of international norms and rules and caused widespread fears in the West for Russian challenges to the NATO countries of Estonia, Latvia and Lithuania. The USA and Europe responded to Russian action with a range of economic and technological sanctions against Russian Arctic offshore oil and gas development cutting it off from financing and technology. In the framework of this Russian-Western conflict, Russia has been forced to consider strategic alternatives, where the Sino-Russian relationship looms large. Europe is a big customer of Russian Arctic oil and gas. The Ukraine conflict brought much stronger urgency and attention to the question of Europe's import of Russian gas and the importance of European energy security and diversifying energy supplies away from overdependency on Russia.

\section{Rising China, Post-Cold War Russia and the Arctic}

The confluence of the end of the Cold War and globalization driven by the rise of China are clear in the Arctic, both on land and at sea. ${ }^{1}$ This paper discusses the Russian Far East and the Bering region concerning the cases of cross-border exchange, trade and investment in agriculture, commodities and processed goods, oil and gas trade and investment, and Arctic shipping. This discussion will demonstrate potentially particularly dramatic effects of these twin international developments for the Pacific Arctic, more dramatic than in other parts of the Arctic.

Russia (and the USSR) combined historically and today being state and empire at the same time. Russia has an enormous sparsely populated territory with no natural borders. These borders have ebbed and flowed historically. Unlike China, Russia has usually bordered higher developed centers of power than itself. Therefore the periphery has been more important than the center for Russia (unlike China). With these porous borders and powerful neighbors, Russia has always thought geostrategically in terms of time and space. Space could be sacrificed to an invader in exchange of time to turn the time as with Napoleon or Nazi Germany. Therefore maximizing imperial space in all directions is a Russian geostrategic instinct, which is also at play in its Far East with historically fluid borders and a very powerful and rising China (Cheng 2011).

The setting is a resurgent China with a population of $1.3+$ billion people and a dynamic and increasingly innovative and entrepreneurial economy sourcing energy and raw materials globally. Russia has a bit more than a tenth of China's population and an economy dominated by the energy and raw materials of its enormous territory. Looking at the Russian Far East, a Russian population of 6 millions borders dynamic Chinese regions of 90 million inhabitants. Chinese - and other Asian - economic engagement becomes more and more important in Russian Far Eastern cities. Political-historically, Russian control of some of these border regions

\footnotetext{
${ }^{1}$ The USA is naturally a very present force in this region, and one can revisit the notion of the "romantic triangle" of the USA, the People's Republic of China and the USSR from the Cold War, where the USA held the pivotal position (Wishnick 2015).
} 
only stretches back into the 1800 s and clash with historical Chinese claims to these regions. In fact, Russia's relative weakness in the Pacific was crystallized by the disastrous Russo-Japanese war of 1904-1905. Russia lost her only Pacific warm-water port, most of her Pacific - and Baltic - fleet. History is tending to repeat itself a little over a century later with Russia's relative loss of power with the end of the Cold War and China's resurgence, which comes together forcefully in this region with potentially dramatic effects for Russia. It is worth noting that as recently as the turn of the 20th Century wars have been fought to define the present boundaries of China (and Manchuria), Japan and Korea. In fact for at least two of the Pacific Kuril Islands World War II continues without a Peace treaty. Since this island chain extends as far north as the Russian Kamchatka peninsula, it's possible strategic importance is unknowable. There is also a present Sino-Russian disagreement that goes back to the 1990s when most of the demarcation was settled between Russia and China along the Amur River except for two islands in the river. The islands are close to the major Siberian city of Khabarovsk of strategic importance to Russia.

This discussion of the Pacific Arctic and the Sino-Russian relationship is particularly valuable for Nordic and North Atlantic Arctic researchers and observers, for whom the Pacific Arctic is distant geographically and mentally. In the Nordic and North-Atlantic Arctic there is a sentiment that China and Northeast Asia is far removed from the (Nordic and North Atlantic) Arctic. There is less realization, that there are vast Arctic marine and terrestrial areas in the Russian Far East and the Bering region, that are geographically close to Northeast Asia and notably Northeastern provinces of China. Above it was outlined how globalization drives Chinese and other Asian attention to the Arctic, where sourcing of energy and raw materials and access to new shippinglanes are important. Here there has been a tendency in North Atlantic and Nordic Arctic research and public debate to focus on possible Chinese investments in Iceland or Greenland, which has raised suspicions and domestic political controversies, or the business potentials of trans-Arctic shipping for areas of Northern Fennoscandia and Iceland (Breum, Chemnitz 2013, Utanríkisráđuneytið 2005, Anonymous2010, Lanteigne 2010, Lanteigne 2008, Underhill 2010, Utanríkisráđuneytið 2007). There has been little attention to SinoRussian relations concerning energy and raw materials in the enormous Russian Arctic or the Bering end of trans-Arctic shipping routes, which involves the USA, Japan, and South Korea.

\subsection{Sino-Russian Cross-Border Trade and Interactions}

Looking at Russian and Chinese border cities along the Amur River, such as Blagoveshchensk on the Russian bank of the Amur River and Heihe on the Chinese side, illustrates the demographic and economic imbalances with large Chinese populations in growing cities with high rises and production bordering much smaller and less dynamic Russian cities. And this is a region of Russia which was only claimed for Russian about 150 years ago at the time when European colonial powers were encroaching in China from all sides - which the People's Republic of China has been determined to correct.

Cross-border collaboration along China's and Russia's 4,000 km long common border is a high priority for the central governments of both states, but this collaboration has far from reached the anticipated level. The reasons for the unfulfilled promises of this collaboration are illustrative for our discussion of larger international political and economic systemic effects here. The high-level attention to cross-border collaboration is clear from the Program of Cooperation between the Northeast of the People's Republic of China and the Far East and Eastern Siberia of the Russian Federation (2009-2018), which was signed by Chinese and 
Russian leaders during the United Nations General Assembly in New York in September 2009. This Program has subsequently been mentioned following bilateral meetings of Chinese and Russian premiers and presidents (Cheng 2015).

Despite this high-level commitment, Cheng (2015) shows based on fieldwork that of the 339 projects outlined by the Program to create a transnational corridor and facilities for energy processing only $13.3 \%$ were compleeted, $19.5 \%$ were partly completed and $67.3 \%$ were uncompleted. This state of affairs in particular raises concerns on the Russian side. The trade pattern between the two sides is clear with Russia exporting commodities and energy to China, which in turn exports processed goods. Therefore, Japan and South Korea are also in fact the most important trading partners of two of the Northeastern Chinese regions, Liaoning and Jilin, rather than Russia. As outlined above, China has an almost insatiable demand for energy and raw materials to feed it rapidly growing and in absolute terms enormous economy. It is therefore natural, that China will be very interested in sourcing raw materials from the Russian Far East and Eastern Siberia. There are large potentials for developing raw materials extraction and agricultural production in the Russian Far East and Eastern Siberia of great interest to Chinese buyers. Russia overall lacks capital for this development and workforce in the region to carry out this development. China has plenty of both capital and workforce. However, Chinese investment and labor engagement in Russian raw materials extraction and agriculture is severely hampered by Russian distrust and fear of losing control over these raw materials and lands to Chinese investment and population. Older Russians still remember Chinese claims to previous Chinese lands during the Sino-Soviet split (although settled in the 1990s). Cheng references widespread Russian elite and student fears of Chinese designs on the Russian Far East and Eastern Siberia.

Agriculture is a valuable case to consider in greater depth for these cross-border relations. China is deeply preoccupied with food security for its enormous population, and agriculture is one of the very most important policy areas for its leadership. This concern with food security has led to very intense farming in China including extensive use of fertilizer, which is threatening the environment and the quality of food (food safety). Chinese agriculture is also causing a national water crisis. Intensive Chinese farming has also led to well-developed Chinese agricultural technology. Northeast China is one of the main agricultural regions of China of key importance to Chinese food security and holding much agricultural capital and expertise. The Russian Far East and Eastern Siberia has sizeable arable lands (although limited by, for instance, indigenous reindeer pasturing). However, much of this land is not cultivated because of the low and declining population of the region. Therefore there are none of the environmental and food safety problems on the Russian side. Russia has tried to increase the cultivation of these lands offering free land to new settlers. However, this policy has not been successful stemming or reversing the outflow of population to western parts of Russia. There is therefore apparently potential for agriculture in the Russian Far East and Eastern Siberia supplying high quality food to Chinese consumers. However, again such potential is severely hampered by Russian opposition to Chinese investment and labor import for fear of land-grabbing and loss of control of land (Xiao 2015).

Russian apprehensions about Chinese investments in raw materials and presence of Chinese laborers probably reflect the centuries old characteristic of Russian (and Soviet) economy of "power property rights", which reflect Russian socio-economic historical development since Ivan III in the late 1400 s. A fundamental economic difference between Russia and the West is in terms of property rights. In the West, property rights were distinct from political power allowing private entrepreneurship to develop. The Tsar, the USSR and now President Putin has never allowed such a distinction, where political power has always appropriated property rights and collected rents, usually of natural resources (Cheng 2013). This institutional setup both reflects Russia as a 
natural resource-based economy and keeps Russia as such. This historical difficulty separating political sovereignty and private property rights is perhaps also part of the problem of Russia to allow Chinese investment and labor in natural resource extraction and agriculture.

\subsection{Sino-Russian Gas Agreements in the Shadow of the Ukraine Crisis}

Above it was outlined how mismanaged Russian-West post-Cold War geopolitical competition in the Caucasus and Eastern Europe escalated into the Ukraine crisis and how this crisis cut Russia off from Western finance and technology for its future Arctic offshore oil and gas basis and put Russia's energy trade with Europe into question. Russia had to respond by showing that it had alternative options to Europe, and that alternative was China. Therefore Russia and China concluded two large gas-sales agreements in 2014, which had been under negotiation. However, the advantageous terms of the agreement for China suggests the lack of options for Russia and therefore bargaining power of China - which illustrates well the combination of the end of the Cold War weakening of Russia and the rise of China (O'Sullivan 2014).

Another example of this Sino-Russian Arctic energy relationship is concerning the large Yamal Liquified Natural Gas (LNG) project. The Yamal Peninsula juts out from Siberia into the Arctic Ocean. One side of the peninsula bounds the Kara Sea. This LNG project is in the early stages so costs and production are preliminary and definitely influenced by the sanctions placed on Russia. However, striking a balance using historical data, estimated cost of the project is 27 billion USD to full production in 2025 and interim production in 2017. Despite the sanctions placed upon Yamal's majority stakeholder, the private Russian gas company Novatek, production has slowed but not stopped. The 27 billion USD investment project is $50.1 \%$ owned by Novatek, $20 \%$ owned by Total, $20 \%$ by China National Petroleum Corporation (CNCP) and $9.9 \%$ by China's Silk Road Fund, which ties this project to the One Belt, One Road policy. The objective is to tap into Northwest Siberia's extensive natural gas reserves, which are estimated to contain $84 \%$ of Russia's total natural gas. Ultimately, Yamal will export 16.5 million tons of LNG a year. The funding for this project is global, Russia, France, China. In addition, the infrastructure of pipelines, etc., is internationally funded as well. Extending these relations further, China and Russia have been haggling for 20 years, but did finally sign a $\$ 700$ billion agreement for gas deliveries, which is about $17 \%$ of Beijing's annual consumption, under the shadow of the Ukraine crisis as mentioned above (TASS Russian News Agency 2016, Reuters 2016).

\subsection{Arctic Shipping and the Bering Sea Region}

Turning to the seascape of the Bering region, any vessel from the Atlantic Arctic leaves the Arctic Ocean into the Beaufort and Chukchi Seas and proceeds to the Bering Strait separating the Chukotka Peninsula from Alaska and into the Bering Sea. Some of this transit is potentially perilous for the vessel especially through the Bering Strait, especially in ice-choked winter months. This strait is about $85 \mathrm{~km}$ wide and 30-50 m deep. It contains rock outcroppings and two small islands, Big and Little Diomede. The extremely limited maneuverability of large container and oil tanker vessels is a further concern. After entering the Bering Sea the vessels have some options to move themselves from winter high seas and gales. One of these is to use the islands of the Aleutian Island chain beginning approximately in the two Pribilof Islands and extending into Russian waters at the Commandorski Islands. The point here is that these islands, and the waters of the Bering Strait, are owned by 
both Russia and the U.S. Of course, vessels leaving any of the Russian or Asian countries ports must travel this route in reverse.

Another point is that vessel passage from beginning to end, from European Arctic to Asian Arctic, is adjacent to a significant land mass, owned and administered from Moscow. This has demographic consequences as Russia constantly battles outmigration everywhere from Siberia southward to China's northern border. As one proceeds southerly past Vladivostok the climate moderates and the fertility of the land increases. With a decreasing Russian population Chinese are attracted northward. Even the goods manufactured and the produce grown have a tendency to travel southward exacerbating local tensions.

How these dynamic demographic circumstances combined with climate change will affect the future remains to be seen. Indeed, it possible to hypothesize that in the future that same vessel will not turn southward but rather will find an (as yet unbuilt) deep water port in Chukotka connected to a (as yet unbuilt) railroad terminal running southward. As can be seen, the future of the two potential passages across the Arctic Ocean to realize their potential rests on much that lies outside of the Arctic.

\section{The Pacific Arctic and the Circumpolar Arctic under Globalization: China in the Arctic Council}

The dependence of Russia on China driven both by Russia's post-Cold War international position and globalization with the return of China suggests both an increased reliance of Russia on China and role for China in the Arctic. The logic of the "Chinese Dream" of both domestic prosperity and international recognition will push for China being increasingly involved in Russian energy and raw material extraction in Russia and the Russian Far East. It will also increase the role of China in Arctic Ocean maritime affairs and governance, and consequently in Circumpolar Arctic governance. As China becomes a larger economic and political force in the world - although growing slower than before - it is likely to request a larger role in regional governance around the world (Mearsheimer 2001), including the Arctic. In May 2013, the Arctic states chose to solve the fundamental policy question of power transition whether to contain or integrate rising powers by integrating the rising powers in a junior position as observers while demanding their acquiesce to the institutions of the status quo powers (the sovereignty of Arctic states).

It remains to be seen whether China - as any rising power - in the long run will abide by such a policy by the status quo powers, or demand a greater say in Circumpolar Arctic governance. The Sino-Russian(-American) relationship in the Pacific Arctic will be central to this question. Russia may either be dependent on China for the twin reasons outlined here, or seek to stem Chinese influence in the Arctic (for the same reasons), which will be exceedingly difficult (again for the same twin reasons). The role of the USA as the third major player in the Pacific Arctic and the superpower of the international system will be central. 


\section{Conclusion}

The place of the Arctic in the international political and economic system is a central question for understanding the history, present and future of the Arctic. The Arctic has historically been economically integrated into Southern economies, and it has been a major theatre of military operations in geopolitical competition between great and super powers during World War Two and the Cold War. Today, the Arctic is much shaped by the twin international political and economic systemic changes of post-Cold War Russia-West relations and globalization driven by the return of China to its historical place in the world economy. For Arctic research in the West, especially Nordic and North-Atlantic, the Pacific Arctic is a far away region of which people know little, and China - and other Asian observer states in the Arctic Council - are assumed to be far from the Arctic. There is less analysis or discussion of the repercussions of these international political and economic systemic developments for the Pacific Arctic and through that region on the Circumpolar Arctic. This article has sought to analyze and discuss such repercussions. The two co-authors represent the Nordic and North Atlantic Arctic in Troms $\varnothing$ and the Pacific (Arctic) in Seattle.

Our finding is that Russian-Western conflicts driven by mismanaged post-Cold War geopolitical competition separate Russia from the West for technology, finance and markets for developing its Arctic energy and raw material resources. This separation forces Russia to turn to alternative sources of technology, finance and markets for its energy and natural resources, which most prominently is China. Russia is comparatively weakened compared to China in this relationship, which was illustrated by the terms of the 2014 Sino-Russian gas-sales-agreements. These post-Cold War dynamics are reinforced by globalization dominated by the phenomenal Chinese economic growth returning China to its historical position in the world economy. To fuel this growth, China has and will continue to source energy and raw materials globally, including in the Arctic. Here Russia is a treasure trove of energy and raw materials. And the Russian Far East is a vast region with a small population of around 6 mio people, while the bordering region in China has a population of 90 mio. Chinese economic engagement in the Russian Far East and migration is met by deep Russian distrust. Historically it is a contested region, where Russian imperial control was formalized in the mid-1800s during the time of Western colonial domination of China, which the People's Republic of China has strived to correct. The Pacific Arctic is therefore the region where the combined consequences of the end of the Cold War and globalization may lead to dramatic shifts in political and economic power and demographics.

The enormous land territory of the Russian Far East is one aspect, the other is the sea-space of the Bering Region. Attention has been devoted to analysing and discussing possible new Arctic sea lanes, where most attention has been focused on ice conditions in the Arctic Ocean. In the North Atlantic and Nordic Arctic, there continues to be much focus on possible regional development possibilities stemming from trans Arctic shipping. Less attention has been devoted to the Bering region entrance to these possible new shipping lanes. The Bering Strait is a bottleneck of shallow depth posing navigational problems, which reinforces the importance of ports and possible rail connections in Russian Far East.

\section{References}


Barents Observer, Iceland invites China to Arctic shipping2010, 22 September-last update [Homepage of BarentsObserver.com], [Online]. Available: http://www.barentsobserver.com/iceland-invites-china-toarctic-shipping.4821566-116321.html [2011, 12 April].

Bertelsen, R.G., Li, X. \& Gregersen, M.H. 2016, "Chinese Arctic science diplomacy: an instrument for achieving the Chinese Dream?" in Global challenges in the Arctic region: sovereignty, environment and geopolitical balance, eds. S. Iglesias Sanchez \& E. Conde Perez, Routledge, Abingdon, pp. nd-nd.

Borgerson, S.G. 2008, "Arctic Meltdown: The Economic and Security Implications of Global Warming", Foreign Affairs, vol. 87, no. 2, 63-77.

Breum, M. \& Chemnitz, J., 2013, No, Greenland does not belong to China, The New York Times, New York, NY.

Cao, C., Suttmeier, R.P. \& Simon, D.F. 2009, "Success in state-directed innovation? Perspectives on China's plan for the development of science and technology" in The new Asian innovation dynamics: China and India in perspective, eds. G. Parayil \& A.P. D'Costa, Palgrave Macmillan, Basingstoke, UK; New York, NY, pp. 247-264.

Cheng, Y. 2015, "Do National Policies Contribute to Regional Cross-Border Integration? The Case of the Program of Cooperation between Northeast China and Russia's Far East and Eastern Siberia (20092018)" in International Cooperation in the Development of Russia's Far East and Siberia, eds. J. Huang \& A. Korolev, Palgrave Macmillan, New York, pp. 202-228.

Cheng, Y. 2013, "Russia's path dependence on the power-property system in the 'long Putin era': its origin and rationale", China Economist, vol. 8, no. 2, pp. 92-109.

Cheng, Y. 2011, "The power of diplomatic traditions: understanding the logic of Russia's foreign policy in the post-soviet era", Eurasian Review, vol. 4, pp. 25-40.

Heininen, L. \& Southcott, C. (eds) 2010, Globalization and the circumpolar North, University of Alaska Press, Fairbanks, AK.

Huang, C., Gouveia, J.J.B. \& Varum, C.A. 2007, China: building an innovative economy, Chandos Publishing, Oxford.

Lanteigne, M. 2010, "Northern exposure: cross-regionalism and the China-Iceland preferential trade negotiations", The China Quarterly, vol. 202, pp. 362-380.

Lanteigne, M. 2008, The falcon and the dragon: commercial diplomacy and the Sino-Icelandic free trade negotiations, University of Iceland, Reykjavík.

Li, X. \& Bertelsen, R.G. 2013, "The Drivers of Chinese Arctic Interests: Political Stability and Energy and Transportation Security" in Arctic Yearbook 2013, eds. L. Heininen, H. Exner-Pirot \& J. Plouffe, Northern Research Forum; University of the Arctic Thematic Network on Geopolitics and Security, http://www.arcticyearbook.com, pp. 1-16.

Lundvall, B., Gu, S., Liu, J., Schwaag Serger, S. \& Malerba, F. 2009, "China's System and Vision of Innovation: An Analysis in Relation to the Strategic Adjustment and the Medium- to Long-Term S\&T Development Plan (2006-20)", Industry and Innovation.16, vol. 16, no. 4-5, pp. 369-388.

Mearsheimer, J.J. 2014, "Why the Ukraine crisis is the West's fault: the liberal delusions that provoked Putin", Foreign Affairs, vol. 93, no. 5, pp. 77-89.

Mearsheimer, J.J. 2001, The tragedy of great power politics, W.W. Norton, New York, NY.

O'Sullivan, M.L. 2014, 11/14-last update, New China-Russia gas pact is no big deal [Homepage of Bloomberg L.P.], [Online]. Available: http://www.bloombergview.com/articles/2014-11-14/new-chinarussia-gaspact-is-no-big-deal [2016, 02/02].

Reuters 2016, 5th of January-last update, China insurance fund to invest in Russia's Yamal LNG [Homepage of Reuters], [Online]. Available: http://www.reuters.com/article/china-insurance-investmentidUSL3N14P1JG20160105 [2016, 03/29].

Schaaper, M. 2009, Measuring China's innovation system: national specificities and international comparisons, OECD Publishing.

Schwaag Serger, S. 2009, "Foreign corporate R\&D in China: Trends and policy issues" in The new Asian innovation dynamics: China and India in perspective, eds. G. Parayil \& A.P. D'Costa, Palgrave Macmillan, Basingstoke, UK; New York, NY, pp. 50-78. 
TASS Russian News Agency 2016, 15th of March-last update, Novatek closes transaction on Yamal LNG 9.9\% stake sale to Silk Road Fund [Homepage of TASS Russian News Agency], [Online]. Available: http://tass.ru/en/economy/862539 [2016, 03/29].

Underhill, W. 2010, 18 March-last update, China eyes investment in Iceland [Homepage of Newsweek], [Online]. Available: http://www.newsweek.com/blogs/wealth-of-nations/2010/03/18/china-eyesinvestment-in-iceland.html [2011, 12 April].

Utanríkisráđuneytið 2007, Ísinn Brotinn: Próun norđurskautssvæđisins og sjóflutningar (Breaking the ice: Arctic developments and maritime transportation), Utanríkisráđuneytið, Reykjavik.

Utanríkisráđuneytið 2005, Fyrir stafni haf: Tækifæri tengd siglingum á norðurslóðum (Open sea ahead: Possibilities regarding navigation in the Arctic), Utanríkisráđuneytið, Reykjavik.

Wishnick, E. 2015, The new China-Russia-U.S. triangle, The National Bureau of Asian Research, Seattle, WA; Washington, DC.

Xiao, H. 2015, "A preliminary study on Sino-Russian agricultural cooperation and its potential risks in the Russian Far East", The Journal of Siberian and Far Eastern Studies, vol. 13, pp. 77-108.

Xie, Y., Zhang, C. \& Lai, Q. 2014, "China's rise as a major contributor to science and technology", Proceedings of the National Academy of Sciences of the United States, vol. 111, no. 26, pp. 9437-9442.

Xu, A. 2008, "China looks abroad: Changing directions in international science", Minerva: A Review of Science, Learning and Policy, vol. 46, no. 1, pp. 37-51. 